Prepared in cooperation with Long Island Water Conference Nassau County Department of Public Works New York City Department of Environmental Protection Port Washington Water District Suffolk County Department of Health Services Towns of North Hempstead and Shelter Island Manhasset-Lakeville Water District Nassau Suffolk Water Commissioners Association New York State Department of Environmental Conservation Sands Point Water Department Suffolk County Water Authority Water Authority of Great Neck North

\title{
Water-Table and Potentiometric-Surface Altitudes in the Upper Glacial, Magothy, and Lloyd Aquifers of Long Island, New York, April-May 2013
}

By Michael D. Como, Michael L. Noll, Jason S. Finkelstein, Jack Monti, Jr., and Ronald Busciolano 


\section{U.S. Department of the Interior \\ SALLY JEWELL, Secretary}

U.S. Geological Survey
Suzette M. Kimball, Acting Director

U.S. Geological Survey, Reston, Virginia: 2015

For more information on the USGS-the Federal source for science about the Earth, its natural and living resources, natural hazards, and the environment-visit http://www.usgs.gov/ or call 1-888-ASK-USGS (1-888-275-8747).

For an overview of USGS information products, including maps, imagery, and publications, visit http://www.usgs.gov/pubprod/.

To order USGS information products, visit http://store.usgs.gov/.

Any use of trade, firm, or product names is for descriptive purposes only and does not imply endorsement by the U.S. Government.

Although this information product, for the most part, is in the public domain, it also may contain copyrighted materials as noted in the text. Permission to reproduce copyrighted items must be secured from the copyright owner.

Suggested citation:

Como, M.D., Noll, M.L., Finkelstein, J.S., Monti, Jack, Jr., and Busciolano, Ronald, 2015, Water-table and potentiometric-surface altitudes in the Upper Glacial, Magothy, and Lloyd aquifers of Long Island, New York, AprilMay 2013: U.S. Geological Survey Scientific Investigations Map 3326, 4 sheets, scale 1:125,000, 6-p. pamphlet, http://dx.doi.org/10.3133/sim3326.

ISSN 2329-132X (online) 


\section{Water-Table and Potentiometric-Surface Altitudes in the Upper Glacial, Magothy, and Lloyd Aquifers of Long Island, New York, April-May 2013}

\section{Sheet 1-Water table}

\section{Introduction}

The U.S. Geological Survey (USGS), in cooperation with State and local agencies, systematically collects groundwater data at varying measurement frequencies to monitor the hydrologic conditions on Long Island, New York. Each year during April and May, the USGS conducts a synoptic survey of water levels to define the spatial distribution of the water table and potentiometric surfaces within the three main water-bearing units underlying Long Island-the upper glacial, Magothy, and Lloyd aquifers (Smolensky and others, 1989) — and the hydraulically connected Jameco (Soren, 1971) and North Shore aquifers (Stumm, 2001). These data and the maps constructed from them are commonly used in studies of Long Island's hydrology and are utilized by water managers and suppliers for aquifer management and planning purposes.

Water-level measurements made in 502 monitoring wells (observation and supply wells) and 16 streamgage locations across Long Island during April-May 2013 were used to prepare the maps in this report. Groundwater measurements were made by the wetted-tape method to the nearest hundredth of a foot. Contours of water-table and potentiometric-surface altitudes were created by using the groundwater measurements. The water-table contours were interpreted by using water-level data collected from 16 streamgages, 334 observation wells, and 1 supply well screened in the upper glacial aquifer or the shallow Magothy aquifer; the Magothy aquifer's potentiometric-surface contours were interpreted from measurements at 70 observation wells and 31 supply wells screened in the middle to deep Magothy aquifer and the contiguous and hydraulically connected Jameco aquifer. The Lloyd aquifer's potentiometric-surface contours were interpreted from measurements at 58 observation wells and 8 supply wells screened in the Lloyd aquifer and the contiguous and hydraulically connected North Shore aquifer. Many of the supply wells are in continuous operation and therefore, were turned off for a minimum of 24 hours before measurements were made to allow the water levels in the wells to recover to ambient (non-pumping) conditions. Full recovery time at some of these supply wells can exceed 24 hours; therefore, water levels measured at these wells are assumed to be less accurate than those measured at observation wells, which are not pumped (Busciolano, 2002). In addition to pumping stresses, elevated chloride concentrations (saline water) also lower the water levels measured in certain wells. This reduction in water level is the result of saline water being denser than freshwater (Lusczynski, 1961). In this report, all water-level altitudes are referenced to the National Geodetic Vertical Datum of 1929 (NGVD 29).

The land surface or topography was downloaded from the National Map portal (http://nationalmap.gov), which represents the most currently available terrain representation as a 10meter digital elevation model (DEM). The National Map terrain representation was combined with additional land surface terrain models of Suffolk County and New York City, which were collected using lidar to produce a high accuracy three-dimensional land surface altitude model based on the 
geospatial product for coastal flood mapping. The datum for land surface altitude is North American Vertical Datum of 1988 (NAVD 88). NAVD 88 is approximately 1 - foot lower than NGVD 29 on Long Island.

Hydrographs are included on these maps for selected wells that have digital recording equipment. These hydrographs are representative of the 2013 water year ${ }^{1}$ to show the changes that have occurred throughout that period. The synoptic survey water level measured at the well is included on each hydrograph.

\section{Upper Glacial and Shallow Magothy Aquifers (Water Table)}

The upper glacial aquifer of Pleistocene age is the uppermost unit in Long Island's groundwater system and contains the water table throughout the island, except in parts of central and eastern Nassau County and western Suffolk County, where the entire upper glacial aquifer is unsaturated and the water table is in the shallow Magothy aquifer. The upper glacial aquifer was the principal source of water supply throughout Long Island for several decades, but contamination in many areas resulted in the widespread curtailment of its use for public supply. The general configuration of the water table is an east-west mound that coincides with the topographic high (region of higher land surface altitude) and the glacial moraine along the center of the island with isolated areas of higher water levels in central Nassau County and in central Suffolk County. Local highs also are present in northwestern Nassau County (Stumm and others, 2002) and the central part of the southern peninsula of eastern Suffolk County (Schubert and others, 2004). These areas of higher water levels are a result of the low hydraulic conductivity of the geologic units underlying these wells.

The water-table altitude on Long Island during April-May 2013 ranged from 0 feet (ft) along the shore to more than $121 \mathrm{ft}$ above NGVD 29 in northwestern Nassau County. In Kings County, 20 measurements ranged from 1.19 to $16.55 \mathrm{ft}$; in Queens County, 34 measurements ranged from 0.74 to $46.39 \mathrm{ft}$; in Nassau County, 71 measurements ranged from 1.84 to $121.71 \mathrm{ft}$; and in Suffolk County, 210 measurements ranged from 1.29 to $78.67 \mathrm{ft}$ above NGVD 29.

\section{References Cited}

Busciolano, Ronald, 2002, Water-table and potentiometric-surface altitudes of the Upper Glacial, Magothy, and Lloyd Aquifers on Long Island, New York, in March-April 2000, with a summary of hydrogeologic conditions: U.S. Geological Survey Water-Resources Investigations Report 01-4165, 17 p., 6 pl.

Lusczynski, N.J., 1961, Head and flow of ground water of variable density: Journal of Geophysical Research, v. 66, no. 12, p. 4247-4256.

Schubert, C.E., Bova, R.G., and Misut, P.E., 2004, Hydrogeologic framework of the North Fork and surrounding areas, Long Island, New York: U.S. Geological Survey Water-Resources Investigations Report 2002-4284, 23 p., 4 pl., scale 1:120,000.

Smolensky, D.A., Buxton, H.T., and Shernoff, P.K., 1989, Hydrologic framework of Long Island, New York: U.S. Geological Survey Hydrologic Investigations Atlas HA-709, 3 sheets, scale $1: 250,000$.

Soren, Julian, 1971, Results of subsurface exploration in the mid-island area of western Suffolk County, Long Island, New York: Oakdale, N.Y., Suffolk County Water Authority, Long Island Resources Bulletin 1, 60 p. 
Stumm, Frederick, Lange, A.D., and Candela, J.L., 2002, Hydrogeology and extent of saltwater intrusion on Manhasset Neck, Nassau County, New York: U.S. Geological Survey Water-Resources Investigations Report 00-4193, 42 p.

${ }^{1} \mathrm{~A}$ water year is the 12-month period beginning October 1 and ending September 30. It is designated by the year in which it ends.

\section{Sheet 2-Potentiometric surface in the Magothy and Jameco aquifers}

\section{Magothy and Jameco Aquifers}

The Magothy aquifer of upper Cretaceous age is the most extensive unit in Long Island's groundwater system. This aquifer underlies most of Long Island and the offshore waters, except in parts of western and northern Kings and Queens Counties, northern Nassau County, and northwestern and northeastern Suffolk County, where it has been removed by erosion and glacial scour. The altitude of its upper surface ranges from more than 200 feet (ft) above the National Geodetic Vertical Datum of 1929 (NGVD 29) in parts of north-central Nassau County and west-central Suffolk County to more than 600 ft below NGVD 29 in north-central Suffolk County (Smolensky and others, 1989). Aquifer thickness ranges from zero in northern and western Kings and Queens Counties, northern Nassau County, and parts of northern Suffolk County to more than 1,000 ft in south-central Suffolk County (Soren and Simmons, 1987). The Magothy aquifer is the principal source of water supply in Nassau and Suffolk Counties.

This map depicts water levels during April-May 2013 in wells screened in the Magothy aquifer and the hydraulically connected Jameco aquifer. Most water-level measurements used to prepare this map were made in wells screened near the middle of the aquifer and were supplemented by some measurements from the basal zone. Only a few water-level measurements made in the upper part of the aquifer were used. Measured potentiometric heads at a given location can vary depending on the depth of the well screen, because vertical hydraulic gradients in the Magothy Aquifer can be large.

The general configuration of the potentiometric surface in the Magothy aquifer is similar to that of the water table, rising gradually from the western part of Long Island to form an east-west-trending mound in Nassau and western Suffolk Counties. The surface of the mound then gradually declines toward the eastern end of Long Island. In areas where deep channels have been eroded into the Magothy aquifer and filled with glacial deposits, the potentiometric-surface contours were drawn from water levels measured in wells screened in these upper glacial aquifer deposits, which are laterally contiguous and hydraulically connected to the Magothy aquifer. The inferred northern limit of the Magothy aquifer, the inferred extent of the Jameco aquifer, and the aquifer in which each well is screened are indicated on this map. Public-supply pumping and elevated chloride levels have lowered the potentiometric surface below NGVD 29 in southern Nassau County (Lusczynski and Swarzenski, 1966).

The altitude of the potentiometric surface in the Magothy aquifer on Long Island during AprilMay 2013 ranged from about $5 \mathrm{ft}$ below NGVD 29 in extreme southwestern Nassau County to more than $80 \mathrm{ft}$ above NGVD 29 in northeastern Nassau County. In Kings County, 2 measurements ranged from 2.77 to $6.58 \mathrm{ft}$; in Queens County, 8 measurements ranged from 4.26 to $32.05 \mathrm{ft}$; in Nassau County, 29 measurements ranged from -4.90 to $80.00 \mathrm{ft}$; and in Suffolk County, 55 measurements ranged from 3.61 to $75.90 \mathrm{ft}$ above NGVD 29. 


\section{References Cited}

Lusczynski, N.J., and Swarzenski, W.V., 1966, Salt-water encroachment in southern Nassau and southeastern Queens Counties, Long Island, New York: U.S. Geological SurveyWater-Supply Paper $1613-\mathrm{F}, 76 \mathrm{p}$.

Schubert, C.E., Bova, R.G., and Misut, P.E., 2004, Hydrogeologic framework of the North Fork and surrounding areas, Long Island, New York: U.S. Geological Survey Water-Resources Investigations Report 2002-4284, 23 p., 4 pl., scale 1:120,000.

Smolensky, D.A., Buxton, H.T., and Shernoff, P.K., 1989, Hydrologic framework of Long Island, New York: U.S. Geological Survey Hydrologic Investigations Atlas HA-709, 3 sheets, scale $1: 250,000$.

Soren, Julian, and Simmons, D.L., 1987, Thickness and hydrogeology of aquifers and confining units below the upper glacial aquifer on Long Island, New York: U.S. Geological Survey WaterResources Investigations Report 86-4175, 3 sheets, scale 1:125,000.

\section{Sheet 3-Potentiometric surface in the Lloyd and North Shore aquifers.}

\section{Lloyd and North Shore Aquifers}

The Lloyd aquifer of upper Cretaceous age is the basal unit of Long Island's groundwater system. This aquifer continuously underlies most of Long Island and the offshore waters, except in parts of western and northern Kings, Queens, and Nassau Counties, and extreme northeastern Suffolk County, where it has been removed by erosion. The upper surface of the aquifer ranges in altitude from less than 100 feet (ft) below the National Geodetic Vertical Datum of 1929 (NGVD 29) in extreme northern parts of Queens County to more than 1,500 ft below NGVD 29 in south-central Suffolk County (Smolensky and others, 1989). Aquifer thickness ranges from zero in northern and western parts of Kings, Queens, and Nassau Counties and extreme northeastern Suffolk County to more than $500 \mathrm{ft}$ in extreme southeastern Nassau and southwestern Suffolk Counties (Soren and Simmons, 1987).

This map depicts water levels during April-May 2013 in 66 wells screened in the Lloyd and North Shore aquifers. Wells screened in the Pleistocene deposits of the North Shore aquifer in northern Nassau County are included because in these areas the North Shore aquifer is hydraulically connected to the Lloyd aquifer (Stumm, 2001; Stumm and others, 2002 and 2004). The inferred northern extent of the Lloyd aquifer, the inferred extent of the North Shore aquifer, and the aquifer in which each well is screened are indicated on this map.

The general configuration of the potentiometric-surface altitude in the Lloyd aquifer is similar to those in the overlying water-table and Magothy aquifers. The potentiometric surface gradually rises from the western part of Long Island to form an east-west-trending mound in eastern Nassau County that continues east into central Suffolk County. The mound then gradually declines toward the eastern end of Long Island. Public-supply and golf-course pumping has lowered the potentiometric surface in the Lloyd aquifer below NGVD 29 in northwestern Nassau County (Stumm and others, 2002).

The potentiometric-surface altitude in the Lloyd aquifer on Long Island in 2013 ranged from about $14 \mathrm{ft}$ below NGVD 29 in northwestern Nassau County to more than $49 \mathrm{ft}$ above NGVD 29 in northeastern Nassau County. In Kings County, 3 measurements ranged from 5.87 to $8.80 \mathrm{ft}$; in Queens County, 7 measurements ranged from 6.59 to $17.38 \mathrm{ft}$; in Nassau County, 49 measurements ranged from -14.25 to $49.48 \mathrm{ft}$; and in Suffolk County, 7 measurements ranged from 14.47 to 37.25 above NGVD 29. 


\section{References Cited}

Smolensky, D.A., Buxton, H.T., and Shernoff, P.K., 1989, Hydrologic framework of Long Island, New York: U.S. Geological Survey Hydrologic Investigations Atlas HA-709, 3 sheets, scale $1: 250,000$.

Soren, Julian, and Simmons, D.L., 1987, Thickness and hydrogeology of aquifers and confining units below the upper glacial aquifer on Long Island, New York: U.S. Geological Survey WaterResources Investigations Report 86-4175, 3 sheets, scale 1:125,000.

Stumm, Frederick, 2001, Hydrogeology and extent of saltwater intrusion of the Great Neck peninsula, Great Neck, Long Island, New York: U.S. Geological Survey Water-Resources Investigations Report 99-4280, 41 p.

Stumm, Frederick, Lange, A.D., and Candela, J.L., 2002, Hydrogeology and extent of saltwater intrusion on Manhasset Neck, Nassau County, New York: U.S. Geological Survey Water-Resources Investigations Report 00-4193, 42 p.

Stumm, Frederick, Lange, A.D., and Candela, J.L., 2004, Hydrogeology and extent of saltwater intrusion in the northern part of the town of Oyster Bay, Nassau County, New York: U.S. Geological Survey Water-Resources Investigations Report 03-4288, 55 p.

\section{Plate 4-Depth to water table}

\section{Depth to Water Table}

This map depicts the depth to the water table beneath Long Island during April-May 2013. Areas in which the depth to water table is shallow are shown in red and indicate areas where potential substructure flooding may occur.

A geographic information system was used to create a continuous surface of the water table using an iterative finite difference interpolation technique with measurements from 334 observation wells, 1 supply well, 16 streamgages, interpreted 10-foot (ft) contour intervals, and the coastline.

The land surface or topography was downloaded from the National Map portal (http://nationalmap.gov), which represents the most currently available terrain representation as a 10meter digital elevation model (DEM). The National Map terrain representation was combined with additional land surface terrain models of Suffolk County and New York City, which were collected using lidar to produce a high accuracy three-dimensional land surface altitude model based on the geospatial product for coastal flood mapping.

The continuous surface of the water-table was adjusted for the vertical datum differences across Long Island. This interpolated surface was then subtracted from the topography at the same location. The results are shown as a continuous depth to water- table map. Field measurements of depth to water (accurate to a hundredth of a foot) are also plotted on the map.

The general configuration of the depth to the water table reflects the topography data; however, because the map scales of the topography $(1: 24,000)$ and water-table altitude $(1: 125,000)$ differ, the horizontal accuracy of the depth to water table is 1:125,000 with a vertical error of plus or minus 5 feet. Areas in which no water-level data were available for comparison are shown in gray; however, in areas along the south shore of Long Island, including marshes and the barrier island, the water-table altitude was assumed to be the National Geodetic Vertical Datum of 1929 (NGVD 29). 


\section{Groundwater-level Data Retrieval}

Groundwater-level data used to create this map product were downloaded from the USGS National Water Information System (NWIS) database (http://waterdata.usgs.gov/nwis/si). The NWIS database consists of more than 850,000 records of wells, springs, test holes, tunnels, drains, and excavations in the United States. Available site information includes well-location and completion information, such as latitude, longitude, well depth, and aquifer. Water-level data from the NWIS database can be queried and used to construct historical time-series hydrographs for wells. As an example, for Suffolk County mapped well "S16783," search NWIS on Site Name "16783" and choose the option button "match any part"; then click Submit. A search will be completed, and a resulting list of site numbers will appear. Click on the Site Number link, and then click on the Field groundwater-level measurements link. 